\title{
PENGARUH SHALAT TERHADAP AKHLAK AL-KARIMAH SISWA DI SMA MUHAMMADIYAH 8 CERME GRESIK
}

\author{
M. Islahuddin \\ Mohammad Ahyan Yusuf Sya'bani \\ Universitas Muhammadiyah Gresik
}

\begin{abstract}
Abstrak: Dalam gambaran umum agama Islam terdapat beberapa istilah di antaranya : Aqidah, dalam akidah sendiri ada dua yang terlihat yaitu Tauhid dan Syirik. Ada Ibadah, di dalam ibadah ada dua hal adalah lillah dan li ghoirillah. Dan Akhlak, ada dua komponen dalam akhlak yaitu akhlak mahmudah dan akhlak madzmumah. Selanjutnya ada Muamalah, dalam muamalah sendiri ada juga yang berhubungan langsung dengan Allah dan ada yang bersosial dengan manusia. Penelitian ini hanya sebatas interaksi sosial dengan manusia yang akhirnya ada kaitannya dengan hubungan dengan Allah. Maka dari itu peneliti mencantumkan teori sosiologi di samping ada teori tentang shalat dan akhlak al-karimah. Metode yang digunakan dalam penelitian ini adalah metode observasi, angket, wawancara, dan dokumentasi untuk mendapatkan data yang berhubungan dengan SMA Muhammadiyah 8 Cerme Gresik dan uji statistik menggunakan rumus product moment dan aplikasi SPSS 16.0 for windows dengan analisis korelasi untuk mengetahui ada tidaknya pengaruh shalat terhadap akhlak al-karimah siswa SMA Muhammadiyah 8 Cerme Gresik tahun ajaran 2018-2019. Adapun sampelnya dari siswa kelas XI yang berjumlah 89 siswa.
\end{abstract}

Kata Kunci: shalat, akhlak al-karimah 


\section{PENDAHULUAN}

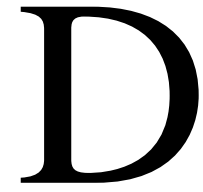
alam rumusan Undang-undang No. 2 Tahun 1989 tentang pendidikan Nasional Bab II pasal 4 dijelaskan bahwa: "Pendidikan Nasional bertujuan untuk mencerdaskan kehidupan bangsa dan mengembangkan manusia Indonesia seutuhnya, yaitu manusia yang beriman bertakwa terhadap Tuhan Yang Maha Esa dan berbudi pekerti luhur, memiliki pengetahuan dan keterampilan, kesehatan jasmani dan rohani, kepribadian yang mantap dan mandiri serta rasa tanggung jawab kemasyarakatan dan kebangsaan” (Depdikbud :1995). Tujuan dari pendidikan nasional sebagaimana yang tercantum dalam UU di atas sebagian sudah tercapai pada hal mencerdaskan. Tetapi dalam hal keimanan, budi pekerti dalam hal ini penulis sederhanakan dengan nama akhlak al-karimahnya masih sangat rendah. Karena masih banyak kasus didunia pendidikan yang sangat mencoreng instansi pendidikan itu sendiri.

Hal ini terbukti ketika penulis melakukan penelitian di Sekolah Menengah Atas Muhammadiyah 8 Cerme Gresik masih adanya kesenjangan antara intensitas siswa dalam mengikuti shalat berjamaah di sekolah dengan akhlak siswa sehari-hari. Hal ini terbukti masih adanya siswa yang bersikap malas, kurang sopan di dalam tertutur kata, membangkang, tidak ada adab kepada guru dan ini mencerminkan masih lemahnya akhlaqul karimah pada siswa. Padahal sudah jelas dalam Firman Allah Qs. Al-Ankabut : 45 “ Sesungguhnya shalat itu mencegah dari perbuatan keji dan munkar”.

Fenomena di atas menarik untuk dipermasalahkan. Bagaimana sebenarnya keadaan shalat siswa di SMA Muhammadiyah 8 Cerme Gresik? Bagaimana akhlak sehari-hari siswa ? Permasalahan yang lebih mendasar lagi adalah sejauh mana dampak/pengaruh shalat terhadap akhlak al-karimah pada siswa, kalau fenomenanya masih bertolak belakang dengan Firman Alah dalam QS. Al-Ankabut: 45.

\section{LANDASAN TEORI}

Muhammad Abdul Malik Az Zaghabi: 2001 menjelaskan bahwa Shalat adalah hubungan yang kuat antara seorang hamba dengan Tuhannya. Hubungan yang mencerminkan kehinaan hamba dan keagungan Tuhan bersifat langsung tanpa perantara dari siapa pun. Penulis mengambil inti sari dari penjelasan tersebut shalat adalah pengikat hubungan yang kuat antara hamba dengan Tuhan-Nya dengan tujuan mengabdi atau menghambakan diri kepada Allah melalui doa yang disertai ucapan dan perbuatan dengan syarat-syarat dan rukunrukun tertentu. Salah satu hikmah dari shalat adalah terletak dalam Qs. Al Ankbut : 45 
yaitu shalat dapat mencegah dari perbuatan keji dan munkar.

Mahmud dan Ali Abdul Halim : 2004 menjelaskan Yang dimaksud dengan Akhlak (moral) adalah sebuah sistem yang lengkap yang terdiri dari karakteristik-karakteristik akal atau tingkah laku yang membuat seseorang menjadi istimewa. Akhlak merupakan salah satu tujuan diadakannya pendidikan sebagaimana yang tercantum dalam UUSPN no.2 tahun 1989. Tentu yang dimaksud akhlak dalam hal ini adalah akhlak al-karimah. Penulis memfokuskan pada adab siswa terhadap guru, sopan santun siswa, dan kedisiplinan siswa.

Max Weber dalam Hotman M. Siahan: 1989 menjelaskan ada tindakan rasional nilai memiliki sifat bahwa alat-alat yang ada hanya merupakan pertimbangan dan perhitungan yang sadar, sementara tujuantujuannya sudah ada di dalam hubungannya dengan nilai-nilai individu yang bersifat absolut. Contoh : perilaku beribadah atau seseorang mendahulukan orang yang lebih tua ketika antre sembako. Maka dari teoriteori di atas sangat tepat dipergunakan untuk landasan penelitian pengaruh shalat terhadap akhlak al karimah siswa.

\section{METODE PENELITIAN}

Penelitian ini adalah penelitian kurangtitatif yang mengembangkan dan meng- gunakan model-model matematis, teori-teori dan/atau hipotesis yang berkaitan dengan fenomena alam. Proses pengukuran adalah bagian yang sentral dalam penelitian kuantitatif karena hal ini memberikan hubungan yang fundamental antara pengamatan empiris dan ekspresi matematis dari hubungan-hubungan kuantitatif. Pada dasarnya penelitian ini dilakukan untuk mengetahui seberapa besar pengaruh shalat terhadap akhlak al-karimah siswa di SMA Muhammadiyah 8 Cerme Gresik.

\section{Variabel Penelitian}

Adapun variabel penelitiannya yaitu ada variabel X : Shalat (variabel bebas) dan variabel Y : akhlak al-karimah siswa (variabel terikat). Lokasi penelitian ini berada di SMA Muhammadiyah 8 Cerme Gresik yang beralamat JL. Morowudi No. 1 Cerme, Morowudi, Kec. Cerme, Kab. Gresik, Prov. Jawa Timur.

\section{Populasi dan Sampel}

Populasi dan sampel penelitian ini adalah kelas XI SMA Muhammadiyah Gresik yang berjumlah 89 siswa. Berhubung jumlahnya tidak memenuhi syarat pengambilan sampel maka penulis mengambil sampel dari keseluruhan populasi tersebut. 
Teknik Pengumpulan dan angket, dan dokumentasi. Dilanjutkan Pengolahan Data pengolahan data menggunakan cara editing,

Teknik pengumpulan data penulis coding, tabulating, scoring.

menggunakan cara observasi, wawancara,

Skor Item Alternatif Jawaban Responden

\begin{tabular}{|c|c|c|c|}
\hline Positif (+) & Skor & Negatif (-) & Skor \\
\hline Selalu & 4 & Selalu & 1 \\
\hline Sering & 3 & Sering & 2 \\
\hline Kadang-kadang & 2 & Kadang-kadang & 3 \\
\hline Tidak Pernah & 1 & Tidak Pernah & 4 \\
\hline
\end{tabular}

\section{Pengukuran Variabel}

Pengukuran variabel penulis menggunakan Skala nominal yakni skala berdasarkan data yang diperoleh dari fasilitas yang dimiliki oleh SMA Muhammadiyah 8 Cerme Gresik. Skala interval yakni skala yang didapat dari hasil responden terhadap angket yang telah diberikan. Maka penulis menggunakan skala likert untuk mengukur sikap, pendapat, dan persepsi seseorang atau sekelompok orang tentang fenomena sosial.

\section{Teknik Analisis Data}

Analisis yang digunakan adalah analisis data kuantitatif, yaitu analisa yang dilakukukah dengan analisis statistik, yaitu :
1. Statistik deskriptif, analisis ini digunakan untuk mengetahui besarnya persentase jawaban angket dari responden. Dengan rumus :

$$
\begin{aligned}
& \text { F } \\
& P=-\quad X 100 \% \\
& \mathbf{N}
\end{aligned}
$$

Keterangan :

$\mathrm{P}$ : Persentase untuk semua jawaban

F : Frekuensi jawaban responden

$\mathrm{N}$ : Jumlah responden

100\%: Bilangan tetap (konstan)

2. Korelasi product moment, cara ini digunakan untuk mencari korelasi antara dua variabel, dengan rumus ; 
$\mathrm{N} \sum \mathrm{XY}-\left(\sum \mathrm{X}\right)\left(\sum \mathrm{Y}\right)$

$\mathrm{r}_{\mathrm{xy}}=$

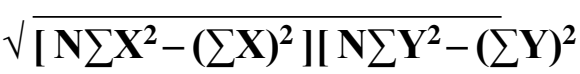

Keterangan :

$\mathrm{r}_{\mathrm{xy}}$ : Angka undeks " $\mathrm{r}$ " product moment (antara variabel $\mathrm{X}$ dan $\mathrm{Y}$ )

$\mathrm{N}$ : Jumlah responden

$\sum X Y$ : Jumlah hasil perkalian antar skor $\mathrm{X}$ dan $\mathrm{Y}$

$\sum \mathrm{X}$ : Jumlah seluruh skor $\mathrm{X}$

$\sum \mathrm{Y}:$ Jumlah seluruh skor $\mathrm{Y}$

Penelitian ini mempunyai tujuan untuk mengetahui apakah variabel X ( shalat ) dan variabel Y (pembentukan akhlak alkarimah) terdapat korelasi yang signifikan. Dari perhitungan itu jika angka korelasi antara variabel $\mathrm{X}$ dan variabel $\mathrm{Y}$ tidak bertanda negatif berarti antara dua variabel tersebut terdapat korelasi positif (korelasi yang berjalan searah).

Cara memberikan interpretasi terhadap angka indeks dalam menginterpretasikan data yang diperoleh, sebagaimana Anas Sudjiono sebutkan dalam bukunya yang berjudul "Pengantar Statistik Pendidikan" yaitu :

a. Memberikan interpretasi angka indeks korelasi product moment dengan pedoman sebagai berikut:

\section{Interpretasi Data}

\begin{tabular}{|c|l|}
\hline Besarnya"r" product moment & \multicolumn{1}{|c|}{ Interpretasi } \\
\hline $0,00-0,200$ & $\begin{array}{l}\text { Antara variabel } \mathrm{X} \text { dan Variabel Y terdapat } \\
\text { korelasi yang sangat rendah }\end{array}$ \\
\hline $0,200-0,400$ & $\begin{array}{l}\text { Antara variabel X dan Variabel Y terdapat } \\
\text { korelasi yang rendah }\end{array}$ \\
\hline $0,400-0,600$ & $\begin{array}{l}\text { Antara variabel X dan Variabel Y terdapat } \\
\text { korelasi yang sedang atau cukup }\end{array}$ \\
\hline $0,600-0,800$ & $\begin{array}{l}\text { Antara variabel X dan Variabel Y terdapat } \\
\text { korelasi yang tinggi }\end{array}$ \\
\hline $0,800-1,00$ & $\begin{array}{l}\text { Antara variabel X dan Variabel Y terdapat } \\
\text { korelasi yang sanagt tinggi }\end{array}$ \\
\hline
\end{tabular}

b. Mencocokkan hasilnya dengan tabel nilai koefisien korelasi " $r$ " product moment baik pada taraf signifikan
$5 \%$ ataupun pada taraf $1 \%$ kemudian dibuat kesimpulan apakah korelasi terdapat korelasi positif yang 
signifikan atau tidak. Dalam penelitian ini peneliti menggunakan taraf signifikasi $5 \%$.

\section{HASIL DAN PEMBAHASAN}

\section{Pengolahan Data}

Pada pembahasan sebelumnya penulis telah kemukakan bahwa salah satu teknik pengumpulan data yang dilakukan adalah melalui angket. Angket yang penulis sebarkan berjumlah 89 angket yang dibagikan kepada sampel sebanyak 89 siswa dari total keseluruhan siswa kelas XI SMA Muhammadiyah 8 Cerme Gresik yang berjumlah 89 siswa yang beragama Islam. Angket yang penulis sebarkan terdiri dari dua komponen pertanyaan yang berjumlah 20 item pertanyaan yang disusun berdasarkan pokok penelitian dan indikator dari variabel yang diteliti, yaitu mengenai pengaruh shalat terhadap moral/ akhlak siswa. Teknik dari pengukuran angket ini menggunakan skala likert dengan bobot nilai sesuai dengan jenis pertanyaan.

Setelah dilakukan tahap penelitian yang meliputi wawancara dan angket, maka langkah selanjutnya adalah pendeskripsian data, yaitu gambaran semua data yang penulis peroleh dari hasil penelitian.

Data yang penulis sajikan dalam skripsi ini adalah hasil penyebaran angket tentang pengaruh shalat terhadap moral / akhlak siswa yang diperoleh dari siswa - siswi kelas XI di SMA Muhammadiyah 8 Cerme Gresik. Adapun hasil pengolahan angket pada teknik deskriptif persentase menggunakan rumus deskriptif statik yaitu Frekuensi jawaban dibagi jumlah responden dikalikan 100 persen maka akan ketemu hasil persentase jawaban responden.

\section{Analisis dan Interpretasi Data}

Dalam penelitian ini dimaksudkan untuk mengetahui apakah secara signifikan terdapat korelasi positif antara pelaksanaan shalat dengan moral (akhlak) siswa. Kemudian penulis menganalisis data dengan menggunakan rumus product moment. Rumus ini digunakan untuk mencapai koefisien korelasi antara dua variabel, yaitu variabel X dan variabel Y. Ditetapkan 89 orang siswa SMA Muhammadiyah 8 Cerme Gresik sebagai sampel berhasil dihimpun data dan diperoleh $\mathrm{N}=89, \sum \mathrm{X}=2552, \sum \mathrm{Y}$ $=2616, \sum X Y=75236, \sum X^{2}=73776, \sum Y^{2}=$ 78502, maka dapat dicari angka korelasi ( rxy ) dengan rumus : 


$$
\begin{aligned}
& \mathbf{N} \sum \mathbf{X Y}-\left(\sum \mathbf{X}\right)\left(\sum \mathbf{Y}\right) \\
& r_{x y}=\frac{}{\sqrt{\left[\mathbf{N} \sum \mathbf{X}^{2}-\left(\sum \mathbf{X}\right)^{2}\right]\left[\mathbf{N} \sum \mathbf{Y}^{2}-\left(\sum \mathbf{Y}\right)^{2}\right]}} \\
& 89 \times 75236-(2552) \times(2616) \\
& =\overline{\sqrt{\left[89 \times 73776-(2552)^{2}\right]\left[89 \times 78502-(2616)^{2}\right]}} \\
& 6696004-6676032 \\
& =\overline{\sqrt{[6566064-6512704][6986678-6843456]}} \\
& 19972 \\
& =\overline{\sqrt{[53360][143222]}} \\
& 19972 \\
& =\overline{\sqrt{7642325920}} \\
& 19972 \\
& = \\
& 87420 \\
& =0,228
\end{aligned}
$$

Dari hasil koefisien korelasi di atas dapat dilihat bahwa antara pelaksanaan shalat dan moral (akhlak) siswa terjadi hubungan atau korelasi yang lemah/rendah. Anas Sujiono dalam bukunya Pengantar statistik pendidikan, membagi kriteria korelasi koefisien sebagai berikut :

$$
\begin{aligned}
& 0,00-0,20=\text { Hampir tidak ada korelasi } \\
& 0,20-0,40 \quad=\text { Korelasi Rendah } \\
& 0,40-0,70 \quad=\text { Korelasi cukup }
\end{aligned}
$$

$$
0,70-0,90=\text { Korelasi tinggi }
$$$$
0,90-1,0=\text { Korelasi cukup tinggi }
$$

Dari data di atas dapat dilihat bahwa analisa tentang pengaruh shalat terhadap moral (akhlak) siswa terdapat korelasi positif ( lemah/rendah ) dengan nilai 0,228 yang terletak di antara 0,20-0,40 dengan korelasi rendah. 


\section{KESIMPULAN}

Berdasarkan hasil penelitian yang telah dilakukan, maka dapat diperoleh beberapa simpulan penelitian sebagai berikut :

Proses pelaksanaan shalat (shalat dhuhur berjamaah) yang dilaksanakan di SMA Muhammadiyah 8 Cerme Gresik adalah, shalat dilaksanakan pada saat menjelang jam istirahat kegiatan belajar mengajar atau pada saat memasuki waktu shalat dhuhur yang dilaksanakan secara berjamaah, dan dipimpin oleh guru ataupun Kepala sekolah. Adapun bagi siswa perempuan yang berhalangan atau haid, mereka berkumpul diruang baca perpustakaan untuk dibimbing materi tentang kewanitaan oleh ibu guru yang bertugas.

Dalam meningkatkan kualitas keagamaan siswa, terutama dalam melaksanakan shalat wajib lima waktu, SMA Muhammadiyah 8 Cerme Gresik banyak mengadakan kegiatan yang bersifat keagamaan di antaranya: Diwajibkannya mengikuti kegiatan shalat berjamaah pada waktu dhuhur disekolah, Adanya kegiatan Darul Arqam waktu bulan Ramadhan. Dan praktik keagamaan waktu pelajaran agama. Adapun persentase jawaban angket pada pelaksanaan shalat adalah Selalu (45,6\%), Sering (23,8\%), Kadang-kadang (20,8\%), dan Tidak pernah $(9,7 \%)$. Sedangkan persentase jawaban angket moral (akhlak) adalah Selalu
$(38,1 \%)$, Sering $(27,5 \%)$, Kadang-kadang $(25,5 \%)$, dan Tidak pernah $(8,9 \%)$.

Pengaruh shalat terhadap akhlak alkarimah siswa SMA Muhammadiyah 8Cerme Gresik tergolong rendah/ lemah. Hal ini ditunjukkan dengan hasil analisis menggunakan product moment dan SPSS 16.0 for windows yang menghasilkan nilai 0,228 yang terletak di antara $0,20-0,40$ dengan korelasi rendah. Dan angka " $\mathrm{t}$ " penelitian sebesar 2,189 > “" $t$ " tabel 0,208 sehingga Ho ditolak dan $\mathrm{Ha}$ diterima. Artinya, terdapat pengaruh positif antara pelaksanaan shalat dan moral (akhlak) siswa di SMA Muhammadiyah 8 Cerme Gresik.

\section{DAFTAR PUSTAKA}

Abdullah , M. Yatimin, 2007, Studi Akhlak dalam Perspektif Al Qur'an. Jakarta: Amzah.

Ahmad, Beni dan Abdul Hamid, 2010, Ilmu Akhlak. Bandung: Pustaka Setia.

Anwar ,Rosihan, 2010, Akhlak Tasawuf. Bandung: Pustaka Setia.

Arikunto, Suharsimi, 2003, Dasar-dasar Evaluasi Pendidikan. Jakarta: Bumi Aksara.

Arikunto, Suharsimi, 1996, Prosedur Penelitian Suatu Pendekatan Praktek. Jakarta: PT Rineka Cipta. 
M. Islahuddin \& Mohammad Ahyan Yusuf Sya'bani -Pengaruh Shalat Terhadap...

Daradjat, Zakiyah, 1993, Pendidikan Islam dalam Keluarga dan Sekolah. Bandung; Remaja Rosdakarya..

Departemen Agama RI, 2011, Al Qur'an dan Terjemahnya.

Depdikbud, 1995, Undang-Undang Sistem Pendidikan Nasional. Jakarta: Sinar Grafika.

Deswita, 2010, Akhlak Tasawuf, Batusangkar: STAIN Batusangkar Press.

Ghozali, M. Syukri, 2015, Pengaruh Kreatifitas Guru Pendidikan Agama Islam Terhadap Peningkatan Pembelajaran Pendidikan Agama Islam di SMP Negri 3 Kota Tangerang Selatan. Jakarta: Jurusan PAI Fakultas dan Keguruan UIN Syarif Hidayatullah.

Hadi, Amirul dan Haryo, 1998, Metode Penelitian Pendidikan. Bandung: CV Pustaka Setia.

Halim, Ali Abdul, dan Mahmud, 2004, Akhlak Mulia. Jakarta: Gema Insani.

http://masbronur.blogspot.com/2017/05/bel ajar-sholat-seperti-tuntunan.html 20/Des/2018, pukul 08:30.

https://id.wikipedia.org/wiki/Penelitian_kua ntitatif 20 Desember 2018 pukul 13:18. https://tradukka.com/translate?hl=es 1 Juli 2019 pukul : 18.02

Khalil, Mustafa, 2004, Berjumpa Allah Dalam Shalat. Jakarta: Pustaka Zahra.
Nazir ,Muhammad, 1998, Metode Penelitian. Jakarta: Ghalia Indonesia. Rasyid, Sulaiman, 2005, Fiqih Islam cet. ke8. Yogyakarta: Sinar Baru Albesindo. Rifa'I, Moh., 2003, Risalah Tuntunan Shalat Lengkap, Semarang: CV Toha Putra.

Pimpinan Pusat Muhammadiyah, 2015, Himpunan Putusan Tarjih. Yogyakarta: Suara Muhammadiyah.

Saintlânâ, 2007, Târîkhul Madzâhib al Falsafiyyah, Juz I, hlm. 174 dalam al Falsafah al Akhlâqiyyah al Aflâthûniyyah 'inda Mufakkiril Islâmî, Dr. Nâjî at Takrîtî, Darul Andalus, Beirut.

Ash-Shidiqy, Tengku Muhamad Hasby, 2000, Pedoman Shalat,Semarang: PT. Pustaka Riski.

Sugiono, 2008, Metode Penelitian Pendidikan; Pendekatan Kuantitatif, Kualitatif, dan $R \& D$. Bandung: Alfabeta.

Sudjiono, Anas, 2014, Pengantar Statistik Pendidikan. Jakarta: PT Raja Grafindo. Yunus, Muhammad, 1990, Kamus ArabIndonesia. Jakarta: PT. Hida Karya Agung.

Zaghabi, Muhammad Abdul Malik, 2001, Malang Nian Orang Yang Tidak Shalat. Jakarta: Pustaka Al Kautsar.

Zahrudin, 2004, Pengantar Studi Akhlak. Jakarta: PT. Radja Grafindo Persada.. 
Jurnal TAMADDUN - FAI UMG. Vol. XX. No.2 / Juli 2019

Zainudin, Rafiudin dan Almi, 2004, Terapi

Kesehatan Jiwa Melalui Ibadah Shalat.

Jakarta: Restu Ilahi.

Zuhaili, Wahbah, 2010, Fiqih Islam

Waadillatuhu. Jakarta: Gema Insani. 